\title{
Status Update on the Second-Generation ILC Marx Modulator Prototype
}

\author{
Mark A. Kemp, Andrew Benwell, Craig Burkhart, Ray Larsen, David MacNair, Minh Nguyen, Jeff Olsen \\ SLAC National Accelerator Laboratory \\ Menlo Park, California
}

\begin{abstract}
This paper is a status update of the SLAC P2 Marx. This Marx-topology klystron modulator is a second-generation modulator which builds upon experience gained from the SLAC P1 Marx. There are several fundamental differences between these modulators including the correction scheme, bus voltages, and the control system architecture. These differences, along with preliminary experimental results and the schedule for further development, are detailed in this paper.
\end{abstract}

Keywords- pulsed power, modulators

\section{INTRODUCTION}

At SLAC National Accelerator Laboratory, an effort is underway to develop a klystron modulator for application to the International Linear Collider (ILC). Specifications for this modulator are listed below in Table I. Following on an effort with the SLAC P1 Marx, the SLAC P2 Marx builds upon lessons learned as well as takes a fundamentally different approach to the correction scheme [1-6].

The Marx topology is a common architecture in pulsed power. However, it is not typically utilized for "long-pulse" applications; the SLAC P1 Marx is ground-breaking in this output-regulated, high average power regime. A simplified Marx topology is shown in Fig. 1a. Capacitors are charged in parallel through isolating impedances. After they are charged, the switches close and the capacitors discharge in series through the load. The output voltage is equal to the input voltage times the number of cells. The solid-state implementation of this topology which is utilized in the P2 Marx is shown in Fig. 1b. The cell is charged through diodes and an IGBT and the discharge is through a second IGBT.

TABLE I. ILC LINAC KLYSTRON MODULATOR SPECIFICATIONS.

\begin{tabular}{ll}
\hline \hline Output Voltage & $120 \mathrm{kV}$ \\
Output Current & $140 \mathrm{~A}$ \\
Average Power & $137 \mathrm{~kW}$ \\
Peak Power & $16.8 \mathrm{MW}$ \\
High Voltage Flattop Width & $1.6 \mathrm{~ms}$ \\
Pulse Flatness & $+/-0.5 \%$ \\
Energy Deposited in Klystron & $<20 \mathrm{~J}$ \\
from Gun Spark & \\
Pulse Repetition Rate & $5 \mathrm{~Hz}$ \\
\hline \hline
\end{tabular}

Work supported by the US Department of Energy under contract DEAC02-76SF00515. E-mail: mkemp@slac.stanford.edu
There are several advantages of the Marx topology for utilization in long-pulse modulators. The topology is inherently modular in nature. A Marx cell structure is repeated many times throughout the modulator. This has advantages in building a redundant structure without single-point failures. If a single cell becomes inoperable, it is simply disabled, bypassed, and the bus voltage is raised.

This paper is a brief survey of the SLAC P2 Marx project. Some concepts are mentioned including comparisons to the P1 Marx, an overview of the control system, and some initial bench-top experimental tests on single cells.

\section{EXPERIENCE FROM P1 DEVELOPMENT}

Currently, the SLAC P1 Marx is undergoing lifetime testing. It operates 24 hours a day, 7 days a week into a klystron load. The modulator has had thousands of hours of successful operation. However, there are several key areas which were identified to improve upon in the next generation of Marx modulator.

In the P1 Marx, each functional switch is made up of 15 separate IGBT packages in a series/parallel arrangement. This complicates the control circuitry and protection schemes.

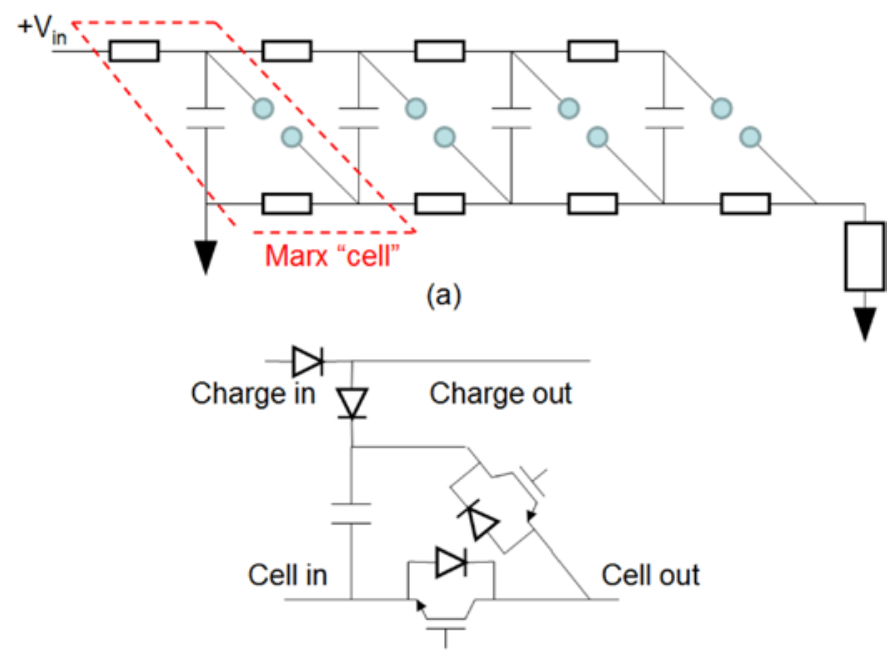

(b)

Figure 1. Simplified schematic of the Marx topology. (a) "Classic" description of the topology. Boxes generically represent charging impedances and the load. (b) SLAC P2 Marx implementation of a single Marx cell. 
Taking advantage of the inherent capability of the Marx topology to electrostatically stack components, each cell is based upon a single, $6.5 \mathrm{kV}$ semiconductor package in the P2 Marx. The maximum output voltage for a single cell is set at $4 \mathrm{kV}$.

Output regulation is achieved in the P1 Marx by delaying the turn-on of several cells. As the output voltage droops, cells are turned on. In addition, a separate "vernier" Marx turns on and off lower-voltage cells for fine-regulation. For the P2 Marx, a more modular approach to regulation is taken: each Marx cell individually regulates its own output. In this nesteddroop correction scheme, cells have a square output pulse, and produce current for the entire pulse.

The P2 Marx is made up for 32 cells each with a nominal operating voltage of $3.75 \mathrm{kV}$. The Marx can produce the necessary output pulse with up to two cells disabled. When a cell is brought offline, the charge voltage is raised up to a maximum of $4 \mathrm{kV}$ to compensate for the disabled cells. This gives the $\mathrm{P} 2$ Marx $\mathrm{N}+2$ redundancy.

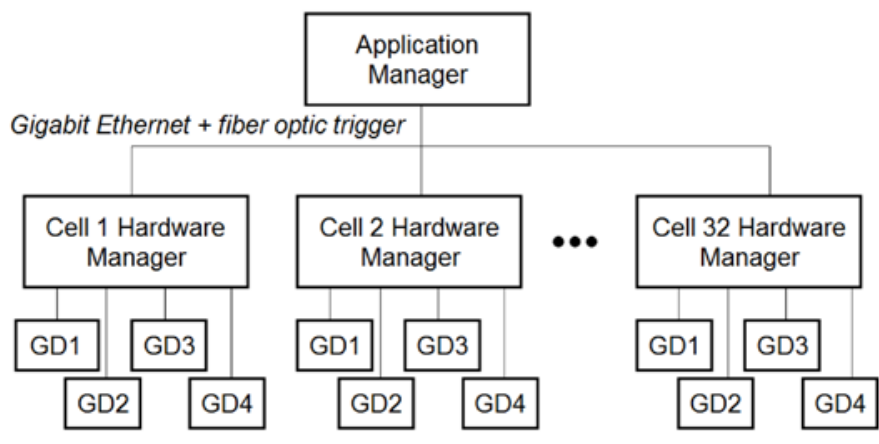

Figure 2. Block diagram of the P2 Marx controls platforms.

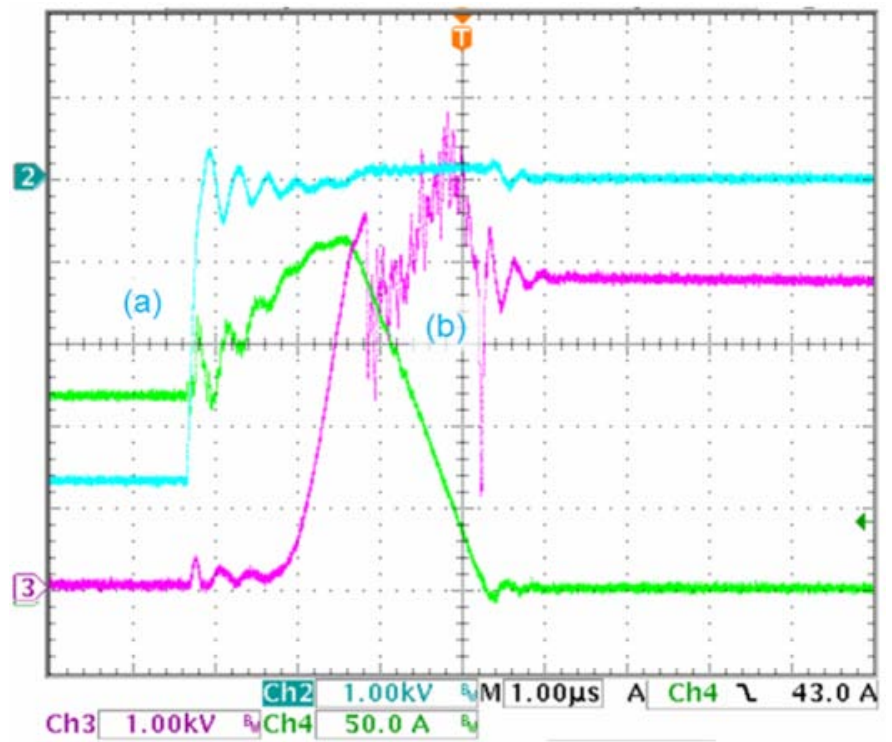

Figure 3. Experimental waveforms of cell during an induced fault. Ch. 2: load voltage, $1 \mathrm{kV} /$ div. Ch3: IGBT $\mathrm{V}_{\text {ce }}, 1 \mathrm{kV} /$ div. Ch. 4 : IGBT collector current, 50 A/div. Fault is induced at (a). At (b), IGBT is turned partially on to suppress an over-voltage condition.

\section{SYSTEM OVERVIEW}

\section{A. Control System Architecture}

A hierarchical control scheme is designed for the P2 Marx [1]. The implementation of this scheme is generically shown in Fig. 2. As shown there are three distinct levels: the gate drives, the hardware manager, and the application manager. Each cell contains four IGBT gate drives and a hardware manager. A single Marx is controlled by the application manager. Gate drives incorporate first-level protection (over current, over voltage, etc.). In addition, they each contain four ADCs which monitor vital signals in the cell. These signals are encoded and are transferred to the hardware manager via a serial link. The hardware manager also has twelve ADCs which, in addition to providing prognostic and diagnostic capabilities, provides the inputs to the cell closed-loop regulation scheme. ADC resolutions vary between 8- and 12-bit, and have sample rates up to $30 \mathrm{MS} / \mathrm{s}$. Each cell communicates with the application manger via a fiber-optic giga-bit Ethernet link.

\section{B. IGBT Gate Drive and Protection}

Mentioned above, the gate drive is a vital part of the modulator's first level of protection [5]. The quickest way to detect and suppress a fault is to locate this circuitry on the gate drive. Implemented in hardware, over current, over $\mathrm{di} / \mathrm{dt}$, and over voltage detection circuitry directly turn-off the cell IGBTs in the case of a fault.

For over-voltage protection, "active snubbing" is used. The IGBT collector voltage is fed back, through appropriately-sized zener diodes to the IGBT gate. When the collector voltage increases past a threshold, the gate voltage is pulled high, and the IGBT partially turns back on. This has the effect of reducing the voltage across the IGBT. Waveforms illustrating this protection are shown in Fig. 3. At point (a) in the figure, a short-circuit fault is induced across the load. Then, current begins to rise through the cell. After the fault is detected, the gate voltage on the IGBT is lowered, and the device starts to turn off. Due to lead inductance and collector di/dt, a voltage spike is induced across the IGBT. At (b), the IGBT voltage oscillates as the gate is turned on and off to clamp the voltage. In this way, the IGBTs are protected from excessive voltage disabling the device.

\section{Preliminary Experimental Results}

Presently, several prototype Marx cells have been constructed. They have been undergoing bench-top testing for

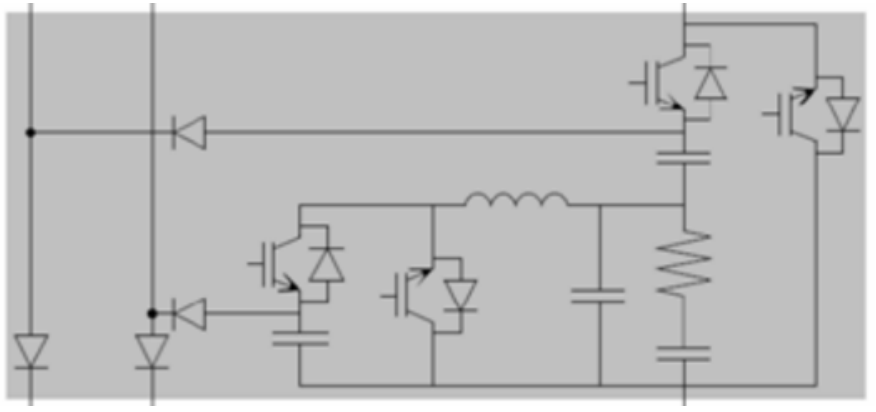

Figure 4. Schematic of the P2 Marx cell. 
about half a year. A simple cell schematic is shown in Fig. 4. There are two bus voltages, $\sim 1 \mathrm{kV}$ and $\sim 4 \mathrm{kV}$, which are fed to the cell via diodes. The cell is composed of a $4 \mathrm{kV}$, "main" portion (shown in the upper right of Fig. 4) and a $1 \mathrm{kV}$, "correction" portion (shown in the lower left of Fig. 4). The final large component in the cell is a LC, PWM filter (shown in the lower right of Fig. 4).

At the start of a pulse, the voltage on the main storage capacitor is at $4 \mathrm{kV}$, the voltage on the correction storage capacitor is $1 \mathrm{kV}$, and the voltage across the PWM filter capacitor is $0 \mathrm{~V}$. During the pulse, as the main storage capacitor droops, the correction portion IGBT chops at the

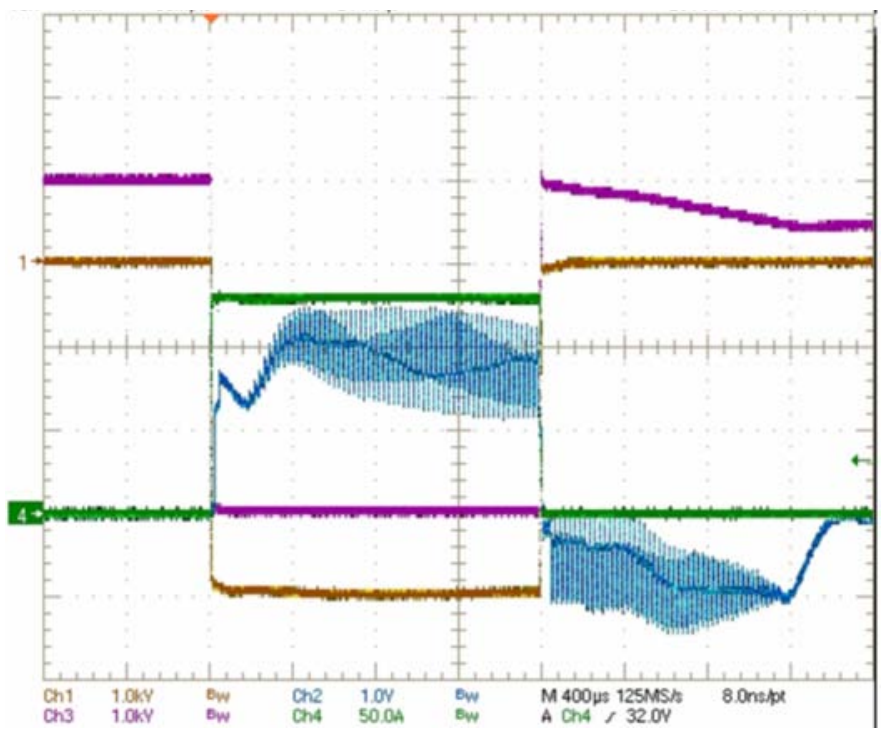

Figure 5. Single cell experimental waveforms illustrating the regulation scheme. Ch. 1: Cell output voltage, 1kV/div. Ch2: PWM filter inductor current, $100 \mathrm{~A} /$ div. Ch. 3: Main IGBT voltage, $1 \mathrm{kV} /$ div. Ch. 4: Cell output current, $50 \mathrm{~A} / \mathrm{div}$.

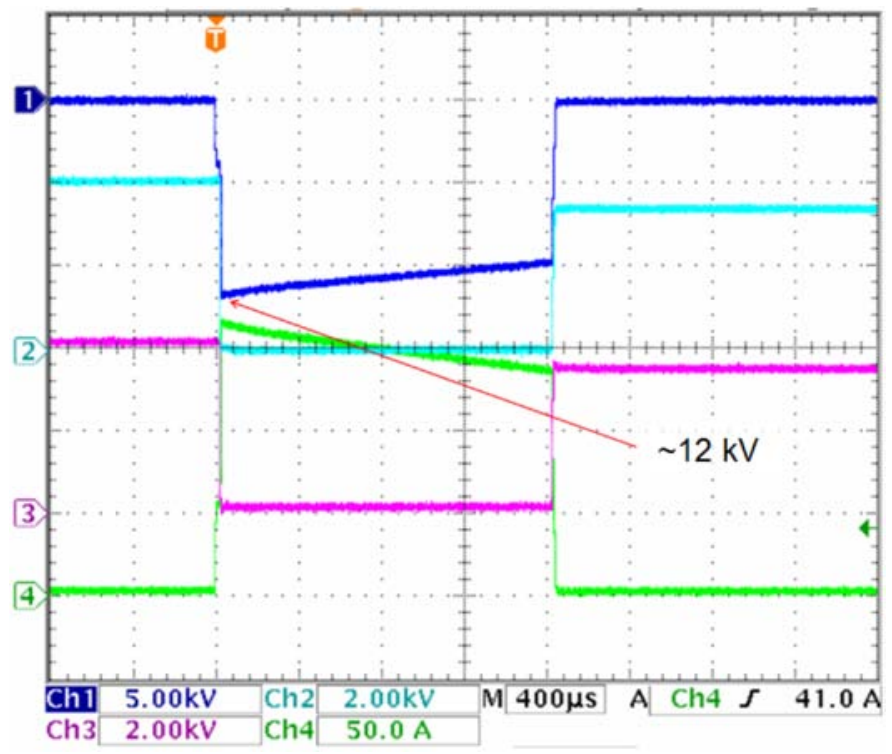

Figure 6. Three-cell experimental waveforms. Cell output is un-compensated, which results in a droop occurring over the length of the pulse. Ch. 1: Marx voltage output, $5 \mathrm{kV} /$ div. Ch. 4 : Marx current output, $50 \mathrm{~A} / \mathrm{div}$.
PWM frequency. This has the effect of increasing the voltage across the PWM filter. The sum of the voltage across the PWM filter capacitor and the main storage capacitor is equal to the cell output. The closed-loop regulation scheme keeps the cell output at a constant $4 \mathrm{kV}$.

Figure 5 shows experimental waveforms with an impementation of the regulation scheme. Channels 1 and 4 are the flat-top voltage and current outputs respectively. Channel 2 is the current through the PWM filter inductor. As shown, the inductor current has a ripple which corresponds to the PWM switching frequency. After the pulse, the energy is recovered from the PWM filter capacitance to the correction storage capacitor. This is necessary in order to reset the voltage across the PWM filter capacitance to zero before the next pulse.

Shown in Fig. 6 are experimental waveforms from a three cell Marx. In this Marx, the outputs are uncompensated to illustrate the droop exhibited when the correction portion of the cell is not utilized. As shown, at the beginning of the pulse, the output is initially three times the $4 \mathrm{kV}$ charge voltage, $12 \mathrm{kV}$.

\section{Mechanical Layout}

The general modulator layout is shown in Fig. 7. Marx cells are inserted into shielded boxes. This way, each cell only "sees" a maximum of $4 \mathrm{kV}$. The first cell is in the upper right. The Marx erects in a serpentine pattern till the last cell in the bottom left. Shown in tan is the support plenum which acts as ducting for the air cooling system.

\section{STATUS AND SCHEDULE}

As of this publication, bench-top validation of the single and three cell Marx is ongoing. This initial validation of the cells will continue until the end of the summer of 2010. During this time, a closed-loop regulation scheme incorporating the hardware manager will be implemented. Also, the design of the full Marx will be completed at this time. The full 32-cell Marx will be fabricated at the beginning of 2011, and developmental

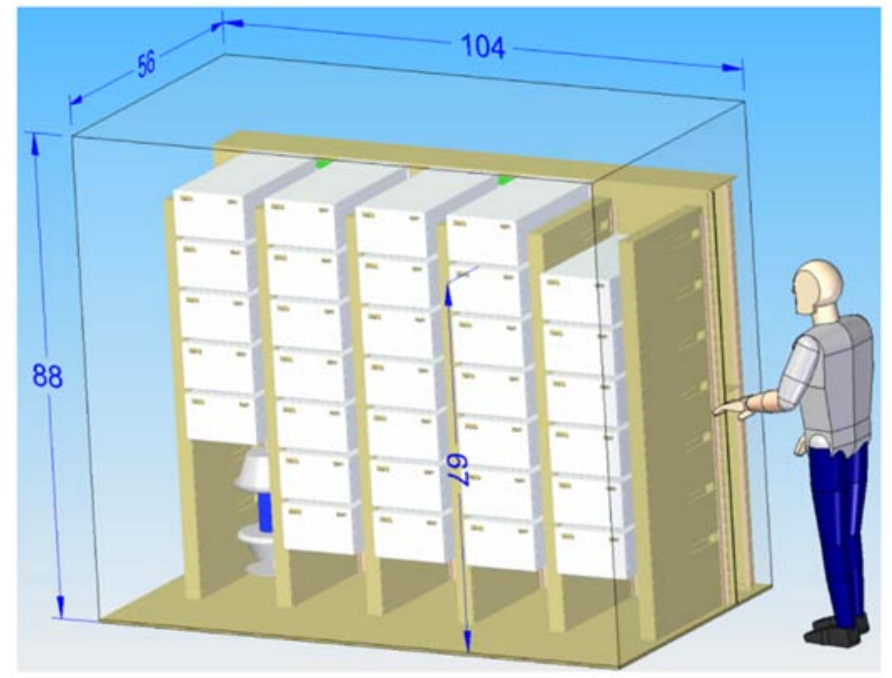

Figure 7. Solid model of the overall P2 Marx layout. Modulator output is to the lower left and dimensions are in inches. 
testing will be finished by October of 2011.

\section{REFERENCES}

[1] K. Macken, et al., "A Hierarchical Control Architecture for a PEBBBased ILC Marx Modulator," in Proc. IEEE Pulsed Power Conference, Washington DC, June 29 - July 2, 2009, pp. 826-831.

[2] K. Macken, et al., "Towards a PEBB-based design approach for a Marxtopology ILC klystron modulator," in Proc. 2009 Particle Accelerator Conf., Vancouver, Canada, May 2009.
[3] C. Burkhart, et al., "P1-Marx modulator for the ILC," presented this conference.

[4] A. Benwell, et al., "A prognostic method for scheduling maintenance on the P2-Marx modulator," presented this conference.

[5] M.N. Nguyen, et al., "Compact, intelligent, digitally controlled IGBT gate drivers for a PEBB-based ILC Marx modulator," LINAC Conf., May 2010.

[6] K. Macken, et al., "Design considerations for a PEBB-based Marxtopology ILC klystron modulator," in Proc. IEEE Pulsed Power Conference, Washington DC, June 29 - July 2, 2009, pp. 811-816. 